\title{
New Extension Approaches for Farmer's Participatory Seed Production Activity in Onion Variety Arka Kalyan for Self-reliance and Doubling the Farmer's Income in Chitradurga District of Karnataka, India
}

\author{
Prakash Kerure*, S. Onkarappa, Rudragouda F. Channagouda and T. Rudramuni \\ ICAR - Krishi Vigyan Kendra, Babbur Farm, Hiriyur, University of Agricultural and \\ Horticultural Sciences, Shivamoga, Chitradurga, Karnataka, India \\ *Corresponding author
}

\section{A B S T R A C T}

\begin{tabular}{l} 
K e y w o r d s \\
$\begin{array}{l}\text { Farmer's } \\
\text { participatory seed } \\
\text { production, Onion } \\
\text { variety Arka } \\
\text { Kalyan, Adoption, } \\
\text { Doubling farmer's } \\
\text { income, Economics }\end{array}$ \\
$\begin{array}{l}\text { Article Info } \\
\text { Accepted: } \\
10 \text { October } 2020 \\
\text { Available Online: } \\
10 \text { November } 2020\end{array}$ \\
\hline
\end{tabular}

Onion [Allium cepa L.] is one of the most important commercial vegetable crops of Chitradurga district. It is mainly grown by small and marginal farmers. It is mainly grown for commercial bulb production during Kharif. Very less number of farmers goes for seed production during Rabi season with local varieties. This new extension approaches may help to farmers for technical interventions on seed production and self-reliance for quality seeds in district. The ICAR-KVK Chitradurga planned to take up quality seed production through participatory seed production in onion variety Arka Kalyan from 2016-17 to 201819. Total 80 farmers by covering area 45 ha were taken up seed production activities and produced 264 q of quality seeds with worth of Rs. 39, 60, 000/-. The spread of Arka Kalyan in the district 3,017 ha that means $10.6 \%$ of total district area under onion. Then the technology is compared with commercial seed production with commercial bulb productions as results shown that the seed production has doubled net returns 7, 10,000 (Rs./ha) as with 2,05,000 (Rs./ha) of an farmer. The cost benefit ratio was 5.3 (seed production/ha) as compare to 3.5 (bulb production/ha. The production of onion gave higher net returns compared to commercial bulb production. The farmers of Chitradurga district for self-reliant of quality seeds and timely availability at their local region by reducing the risk to purchase of seeds from Maharashtra state and also their income was doubled through involving seed production activity from per unit area.

\section{Introduction}

Chitradurga district is located in the Central Dry Zone of Karnataka (Zone IV) with average rainfall of $450-500 \mathrm{~mm}$. onion is the important and commercial vegetable crop grown by small and medium land holding farmers. The district average yield of onion is $19.9 \mathrm{t} / \mathrm{ha}$ but, potential yield is around $30 \mathrm{t} / \mathrm{ha}$, which indicates that there is scope for increasing the productivity and returns. The reasons for lower productivity are poor quality seed material, imbalanced nutrient management, and lack of awareness on plant protection measures and use of local varieties.

Based on the problems observed, the ICARKVK Chitradurga KVK started seed 
production activity in onion through by farmer's participation. Since, it is mainly grown for commercial bulb production during Kharif, very less number of farmers growing seed production during Rabi season with local varieties. In this contest, KVK planned for technical interventions on scientific seed productions and self reliance for quality seeds in district by using improved variety Arka Kalyan.

\section{Scenario of the district and situation analysis}

The area of onion in kharif is around 19,193 ha accounting for around 2 lakh $\mathrm{kg}$ seed requirement. The yields of onion vary from 15 to $20 \mathrm{t} / \mathrm{ha}$ and it has been demonstrated through front line demonstrations that onion bulb yields could be increased by adopting ICM practices and Arka Kalyan variety of IIHR Bengaluru, which is suitable for this region. Seed is the major input for which farmers are dependent on Satara Dist. of Maharastra. But quality is not assured and there are many instances of susceptibility of the variety for pest and disease. Hence, it was felt necessary to train the farmers on scientific seed production technology to ensure self reliance in terms of seed availability in the district.

\section{Materials and Methods}

New extension approaches may help to farmers for technical interventions on seed production and self-reliance for quality seeds in district. The ICAR-KVK Chitradurga planned to take up quality seed production through participatory seed production in onion variety Arka Kalyan from 2016-17 to 2018-19.

\section{Constraints in seed production and marketing}

Low productivity due to lack of technical knowledge in adoption of GAP

Non availability of quality seeds of improved variety

Impure seeds with bolting and splitting of bulbs problems in local variety

Lack of scientific knowledge on seed production and its certification process

Poor handling of seeds, packaging and storages facilities

Less seed viability

Individual farmers marketing of seeds is very difficult until and unless contract farming

\section{SWOT analysis}

\begin{tabular}{|c|c|c|c|}
\hline Strength & Weakness & Opportunity & Threats \\
\hline $\begin{array}{l}\text { Major traditional, } \\
\text { commercial and } \\
\text { economical crop of dist } \\
\text { Suitable soil and } \\
\text { climatic conditions }\end{array}$ & $\begin{array}{l}\text { Low productivity due to } \\
\text { local varieties } \\
\text { Lack of availability } \\
\text { quality seeds of } \\
\text { improved variety } \\
\text { Marketing of seeds }\end{array}$ & $\begin{array}{l}\text { Increase seed demand in } \\
\text { locally of improved } \\
\text { variety } \\
\text { Seed production activity } \\
\text { through groups } \\
\text { Organization of FPO for } \\
\text { seed }\end{array}$ & $\begin{array}{l}\text { Unforeseen climatic } \\
\text { condition } \\
\text { Poor seed set } \\
\text { Fluctuation in seed } \\
\text { price, Bulb splitting and } \\
\text { bolting }\end{array}$ \\
\hline
\end{tabular}

\section{Strategies adopted by KVK}

Based on the constraints faced by the farmers and problems identified by $\mathrm{KVK}$, it was planned to take up quality seed production through front line demonstrations, trainings and organise field days for wider dissemination of the technology (Figure-1).

Large scale demonstrations under "Seed Village Programme" 
In order to ensure quality seed availability in the district, seed production activity was started in Hosakunduru village of Hosadurga Tq. with 80 farmers covering operational area of 40 ha.

\section{Technology demonstrations details}

Onion Seed farmers interested groups (Fig.1) was formed and used in identification of seed farmers \& technological gaps and organization of capacity development.

Arka Kalyan breeder seeds to farmers for quality bulb production during kharif season (Jun-Jul) and seed production during Rabi season (Oct-Nov).

Use of Yellow/Blue sticky traps to control thrips, Bee-colonies to maintain natural pollinators (Honey bees) and Arka Vegetable Special micronutrient for quality seed setting. Seed bulb treatment with bio-inputs like Trichoderma, Pseudomonas and PSB.

Procurement of seeds and Bulk marketing by association: Proper packing and labeling activities, publicity of quality onion seed availability, organization of buyers/sellers meet and organization of district level Field day.

\section{Convergence with line departments/ organisations}

Convergence and linkages with the schemes of line departments and organisations involved in seed production activity, providing drip irrigation system through linkages with State Horticulture Departments, National Horticultural Mission and Mahatma Gandhi National Rural Employment Guarantee Programme (MGNREGP) and NABARD. KVK also developed linkages with Non-Government organisations viz., MYRADA, and GRAMA for promotion of seed production activity by technical support and farm advisories.

\section{Results and Discussion}

\section{Adoption of onion variety Arka Kalyan and area expansion}

Comprehensive interventions of KVK through awareness programmes, training activities, Front Line Demonstrations, advisory services, seed production and convergence with line departments has resulted into a positive outcome in terms of adoption onion variety Arka Kalyan by the farmers of the district. There has been a significant increase in area under onion variety Arka Kalyan. The details of area spread in the district are presented in Figure1.

The information depicted in tables 1-4 reveals that during the period from 2016-17 to 2018-19 the area under onion variety Arka Kalyan is spread to the extent of 3,017 hectares involving 80 farmers. Adoption of onion variety Arka Kalyan in the district is $10.6 \%$ (Fig.1) of its total onion area (Anon, 2018-19)

\section{Economics of onion commercial seed production and commercial bulb production}

Onion cultivation is economically viable for the farmers as compared to local variety which is mainly cultivated in Chitradurga district. Onion variety Arka Kalyan gives returns even during agricultural drought years and resistant to purple blotch. This is in contrast to the local varieties cultivated by the farmers.

The comparison of economics between commercial seed and bulb production of Arka Kalyan variety presented in Table-4 and Fig.2. The results revealed that commercial seed production activity gave high net returns of Rs. 7, 10,000 compared with commercial bulb production of Rs. 2, 05,000. The cost benefit ratio was 5.3 (seed production/ha) as compare to 3.5 (bulb production/ha). 
Table.1 Field extension activities and number of farmers involved (2016-17 to 2018-19)

\begin{tabular}{|c|l|c|c|}
\hline Sl. No. & \multicolumn{1}{|c|}{ Programmes } & No. of programmes & No. of farmers \\
\hline 1. & Training programmes & 69 & 1,964 \\
\hline 2. & Front Line demonstrations & 8 & 80 \\
\hline 3. & OFT & 4 & 12 \\
\hline 4. & Extension activities & 105 & 2,674 \\
\hline
\end{tabular}

Table.2 The year wise seed production of onion variety Arka Kalyan and No. of farmers involved in seed production activities

\begin{tabular}{|c|c|c|c|}
\hline Sl. No. & Year & Seed production $\mathbf{( q )}$ & No. of farmers \\
\hline 1. & $2016-17$ & 192 & 50 \\
\hline 2. & $2017-18$ & 32 & 20 \\
\hline 3. & $2018-19$ & 40 & 10 \\
\hline & Total & $\mathbf{2 6 4}$ & $\mathbf{8 0}$ \\
\hline
\end{tabular}

Table.3 Year wise Expansion of Area under onion variety Arka Kalyan in the District

\begin{tabular}{|c|c|c|c|}
\hline $\begin{array}{l}\text { Sl. } \\
\text { No. }\end{array}$ & $\begin{array}{c}\text { Operational } \\
\text { Year }\end{array}$ & $\begin{array}{l}\text { Participatory Seed } \\
\text { production }(\mathbf{q})\end{array}$ & $\begin{array}{l}\text { Area Expansion in } \\
\text { Chitradurga Dist (ha) }\end{array}$ \\
\hline 1 & 2016-17 & 192 & 2,194 \\
\hline 2 & $2017-18$ & 32 & 366 \\
\hline 3 & 2018-19 & 40 & 457 \\
\hline & Total & 264 & $\mathbf{3 , 0 1 7}$ \\
\hline
\end{tabular}

Table.4 Economics of onion commercial seed and bulb productions

\begin{tabular}{|c|c|c|c|c|c|c|}
\hline Sl. No. & Onion varieties & $\begin{array}{c}\text { Average } \\
\text { yield } \\
\text { (t/ha) }\end{array}$ & $\begin{array}{c}\text { Cost of } \\
\text { cultivation } \\
\text { (Rs./ha) }\end{array}$ & $\begin{array}{c}\text { Gross } \\
\text { returns } \\
\text { (Rs./ha) }\end{array}$ & $\begin{array}{c}\text { Net } \\
\text { Returns } \\
\text { (Rs./ha) }\end{array}$ & $\begin{array}{c}\text { B:C } \\
\text { ratio }\end{array}$ \\
\hline 1. & $\begin{array}{c}\text { Arka Kalyan } \\
\text { (Commercial Bulb } \\
\text { production) }\end{array}$ & 30.0 & 81,378 & $2,86,378$ & $2,05,000$ & 3.51 \\
\hline 2. & $\begin{array}{c}\text { Arka Kalyan } \\
\text { (Commercial Seed } \\
\text { production) }\end{array}$ & 1.25 & $1,65,000$ & $8,75,000$ & $7,10,000$ & 5.30 \\
\hline
\end{tabular}


Fig.1 Adoption of onion variety Arka Kalyan in the district

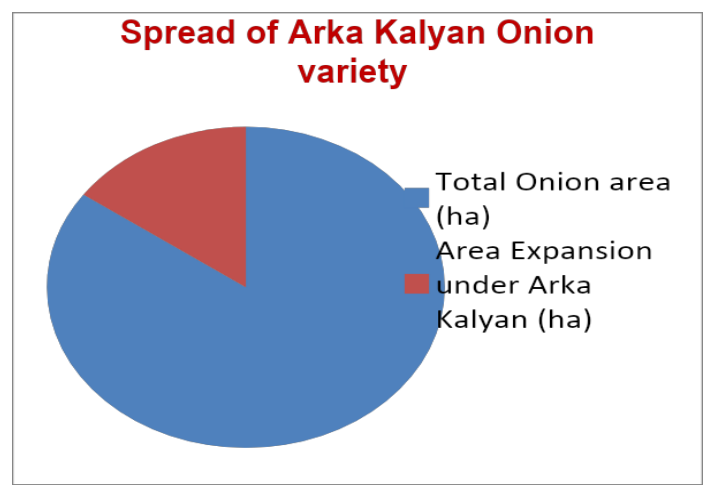

Fig.2 Economics of onion commercial seed production and bulb productions

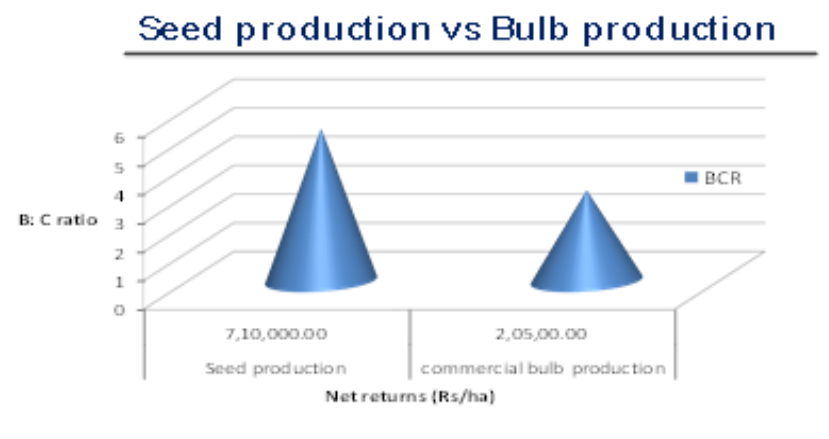

In conclusion the production of onion gave higher net returns compared to commercial bulb production and also provides additional employment generation to family members of farmer. It is helps to farmers of Chitradurga district for self-reliant of quality seeds and timely availability at their local region by reducing the risk to purchase of seeds from neighbouring state and also their income doubled through involving seed production activity from per unit area.

\section{References}

Anonymous, (2018). Chitradurga District at Glance, District statistical Officer, Chitradurga

Basavegouda (2011). Impact of seed village programme for enhancing the availability of quality seeds. National Seed Congress, January, 29-31, 2011,
Mahatma Phule Krishi Vidyapeth, Rahuri and NSRTC, Varanasi, pp. 164165.

Deswal DP, Vinodkumar, VS Mor and Sumit Deswal (2013). Seed replacement rate and its impact on agricultural production of major crops. XIII National Seed Seminar, 8-10 June, 2013, Bangluru, pp. 183-184.

Jhani Rani K, Keshavalu K, Razia Sultana and M Brahmiah (2013). Seed village programme in andhra pradesh: problems and perspectives. XIII National Seed Seminar, 8-10 June 2013.

Shivayogi Ryavalad, R. C. Jagadeesh, Bapurayagouda Patil and Dilleep Masuthi (2020). Impact of ScientistsFarmers Participatory Mode Quality Seed Production in Horticultural Crops, Int.J.Curr.Microbiol.App.Sci., 9 (7): 3248-3254. 
Viswanath K and S Gangadharai (2012). Impact of scientist's farmer's participatory seed production on socioeconomic status of farmers in cauvery command area. National Seed Congress 23-25 January, 2012 Chandigarh, pp. 220.

\section{How to cite this article:}

Prakash Kerure, S. Onkarappa, Rudragouda F. Channagouda and Rudramuni, T. 2020. New Extension Approaches for Farmer's Participatory Seed Production Activity in Onion Variety Arka Kalyan for Self-reliance and Doubling the Farmer's Income in Chitradurga District of Karnataka, India. Int.J.Curr.Microbiol.App.Sci. 9(11): 951-956.

doi: https://doi.org/10.20546/ijcmas.2020.911.113 